\title{
Where's the 'reef'? A five year study of serpulid tube bioerosion in a Scottish sea loch
}

\author{
David J. Hughes* \\ Scottish Association for Marine Science, Scottish Marine Institute, Oban, Argyll PA37 1QA, UK
}

\begin{abstract}
In the British Isles, aggregations of the tubicolous polychaete Serpula vermicularis L. occur only in a few localities in western Scotland and Ireland. In Loch Creran, Argyll, where written observations extend back to the 1880s, build-ups of skeletal debris constituting a true reef framework are notably absent. To investigate the taphonomic processes affecting the residence time of relict tube material, cleaned and weighed skeletal fragments were deployed on panels amongst living worm aggregations. Fragments were either open to the environment or enclosed in mesh cylinders to exclude grazing urchins. Panels were recovered and fragments re-weighed after 1, 2, 3 and 5 yr in situ. Caged fragments typically increased in dry weight over time, while most open fragments remained at steady-state or showed small weight decreases. Change in weight was correlated with the number of living tubeworms which had settled onto the skeletal fragments. Open fragments showed no consistent temporal trend in weight change, suggesting that urchin grazing was not a major bioerosive process over the 5 yr experimental timescale. Data from another locality where serpulid aggregations suffered mass mortality between 1984 and 1994 show that tube debris can persist for at least $15 \mathrm{yr}$ in sea loch environments. $S$. vermicularis aggregations in sea lochs may be relatively transient features, appearing and disappearing over decadal timescales.
\end{abstract}

KEY WORDS: Serpula vermicularis · Bioerosion · Reef · Sea loch · Taphonomy

\section{INTRODUCTION}

Mass occurrences of tubicolous serpulid polychaetes have been described for $\sim 10 \%$ of species in the subfamily Serpulinae and are known from many areas of the world (ten Hove 1979, ten Hove \& van den Hurk 1993). In the British Isles, serpulid aggregations occur only in a few localities on the west coasts of Scotland (Fig. 1) and Ireland (Minchin 1987, Moore et al. 1998). The most extensive examples are found in Loch Creran, a fjordic sea loch in Argyll, west Scotland, where aggregations of Serpula vermicularis L. occupy a narrow depth band (1 to $13 \mathrm{~m}$ ) fringing the loch periphery and covering a total area of $\sim 108$ ha (see Fig. 2 in Moore et al. 2009 for distribution as of July 2005). The $S$. vermicularis aggregations in Loch Creran are regarded as biogenic 'reefs' (Holt et al. 1998), and ongoing scientific studies aim to promote effective conservation management of this rare biotope (Moore et al. 1998, 2003, 2009, Poloczanska et al. 2004, Chapman et al. 2007, Hughes et al. 2008).

Differing concepts of what constitutes a biogenic 'reef' have been discussed at length in both the geological (Heckel \& Yablonsky 1979, Riding 2002) and biological (Hendrick \& Foster-Smith 2006, Rabaut et al. 2009) literature. A feature common to most definitions is the creation of elevated seabed topography by the accumulation of dead skeletal material, providing substratum for continued growth of the 'reef'-building organisms. In Loch Creran, Serpula vermicularis 'reefs' consist of masses of densely-intertwined tubes standing $>50 \mathrm{~cm}$ clear of the seabed and up to $60 \mathrm{~cm}$ in lateral extent (Moore et al. 1998). Mature worms extend their tubes at a mean rate of $33 \mathrm{~mm} \mathrm{yr}^{-1}$ (Hughes et al. 2008). Collapse and subsequent upward regrowth of clusters of tubes create 'ring-reefs' up to $2 \mathrm{~m}$ in diameter (Moore et al. 2009), with total coverage in some areas exceeding $10 \%$ of the seabed (Moore et al. 


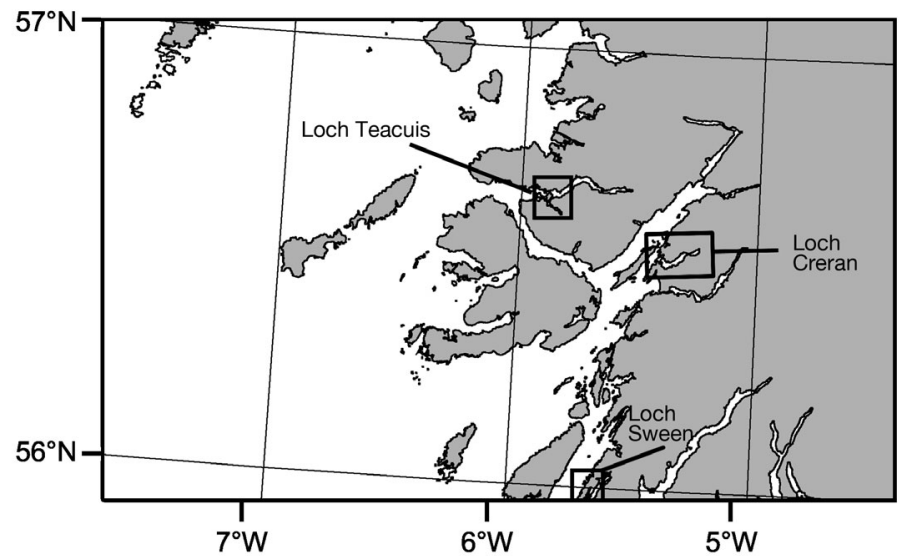

Fig. 1. Scottish west coast, showing locations of the 3 sea lochs with current or former records of Serpula vermicularis aggregations

1998). The $S$. vermicularis aggregations originate on small stones or bivalve shells on a gently-sloping muddy sand substratum (Moore et al. 1998). However, although tube fragments are clearly visible on the seabed in the 'reef' zone, thick deposits of skeletal debris are notably absent (author's pers. obs.). There are no population-level estimates for carbonate production by $S$. vermicularis in Loch Creran, but an observation in 1882 (Anderson Smith 1887) suggests that tubeworm aggregations may have been present in the loch for well over a century. This raises questions concerning the post mortem fate of serpulid tubes in Loch Creran, and the factor(s) which prevent build-up of relict material on the seabed.

In the marine environment, carbonate skeletons can be broken down by a combination of physical abrasion, chemical dissolution and bioerosion (Smith \& Nelson 2003, Wisshak \& Tapanila 2008). Loch Creran is highly sheltered from wave action, and strong tidal currents occur locally only in the entrance channel and at the Creagan Narrows sill (Gage 1972, Moore et al. 1998). In this low-energy setting the rate of physical abrasion is likely to be very low, with chemical dissolution and bioerosion being potentially more significant taphonomic factors. Bioerosion on high-latitude shelves takes place through the action of endolithic algae, fungi, boring sponges and other invertebrates, combined with the grazing activity of macroinvertebrates such as urchins (Wisshak 2006). The urchin Psammechinus miliaris is abundant in Loch Creran (Kelly 2000) and occurs in association with the 'reefs' (Poloczanska et al. 2004). It has been recorded feeding on Serpula vermicularis tubes in Ireland (Bosence 1979) and is therefore potentially an important bioeroder in this serpulid 'reef' habitat.

This paper presents the results of a $5 \mathrm{yr}$ field experiment designed to measure the residence time of Serpula vermicularis tube debris in Loch Creran and investigate the factors affecting skeletal carbonate balance in the 'reef' zone. The work will contribute towards a greater understanding of biogenic 'reef' dynamics in a high-latitude temperate coastal environment.

\section{MATERIALS AND METHODS}

Fieldwork was carried out on the southern shore of Loch Creran at a site $\left(56^{\circ} 30.98^{\prime} \mathrm{N}, 05^{\circ} 22.05^{\prime} \mathrm{W}\right)$ used in an earlier study of survivorship and tube growth (Hughes et al. 2008). Small clusters of tubes containing living Serpula vermicularis were collected by scuba divers in July 2004 and returned to the laboratory. The worms were then killed by overnight immersion in fresh water and extracted from their tubes using forceps. Attached algae and soft-bodied epifauna were also removed. The empty skeletons were then cleaned by $24 \mathrm{~h}$ immersion in dilute sodium hypochlorite solution, washed in running fresh water and dried under low heat in a drying cabinet. Thirty-two skeletal fragments were then individually weighed on an electronic top-pan balance and labelled with a numbered plastic tag held on by a cable tie. The dried fragments were $\sim 15$ to $20 \mathrm{~cm}$ in length with a mean ( \pm SD) dry weight of $43.25 \pm 13.52 \mathrm{~g}$.

Weighed and labelled skeletal fragments were mounted in pairs on square $(30 \times 30 \mathrm{~cm})$ plastic mesh panels and held in place with cable ties. On 8 panels, the skeletal fragments were fully exposed to the environment ('Open' panels, Fig. 2a). On the remaining 8 ('Caged' panels, Fig. 2b) each fragment was enclosed within a plastic mesh cylinder (length $21 \mathrm{~cm}$, diameter $5.5 \mathrm{~cm}$, mesh apertures $5 \times 5 \mathrm{~mm}$ ) designed to exclude urchins. On 15 September 2004, the panels and attached skeletal fragments were returned to the collection site in Loch Creran and deployed on the sea bed by divers among living Serpula vermicularis aggregations. Water depth at the deployment site was $\sim 10 \mathrm{~m}$, with a substratum of gently sloping muddy sand. At $10 \mathrm{~m}$ depth, water temperature in Loch Creran has an annual range of approximately 6 to $12^{\circ} \mathrm{C}$, with a salinity of 32 to 33 psu (Gage 1972). Loch Creran has a relatively high tidal flushing rate (Edwards \& Sharples 1986) and in consequence is always well oxygenated (Gage 1972). The associated fauna of the Loch Creran serpulid 'reef' zone was decribed by Poloczanska et al. (2004).

The panels were deployed in a line roughly parallel to the shore, with a spacing of $\sim 1 \mathrm{~m}$ and Open and Caged panels alternating. Panels were pinned to the sea bed by a $\sim 20 \mathrm{~cm}$ long aluminium rod at each corner, with an upright numbered flag planted next to each one to facilitate relocation on later dives. Recov- 
Fig. 2. (a) Open and (b) Caged panels $(30 \times 30 \mathrm{~cm})$ with attached weighed fragments of Serpula vermicularis tube material, photographed in September 2004 prior to deployment on the seabed in Loch Creran
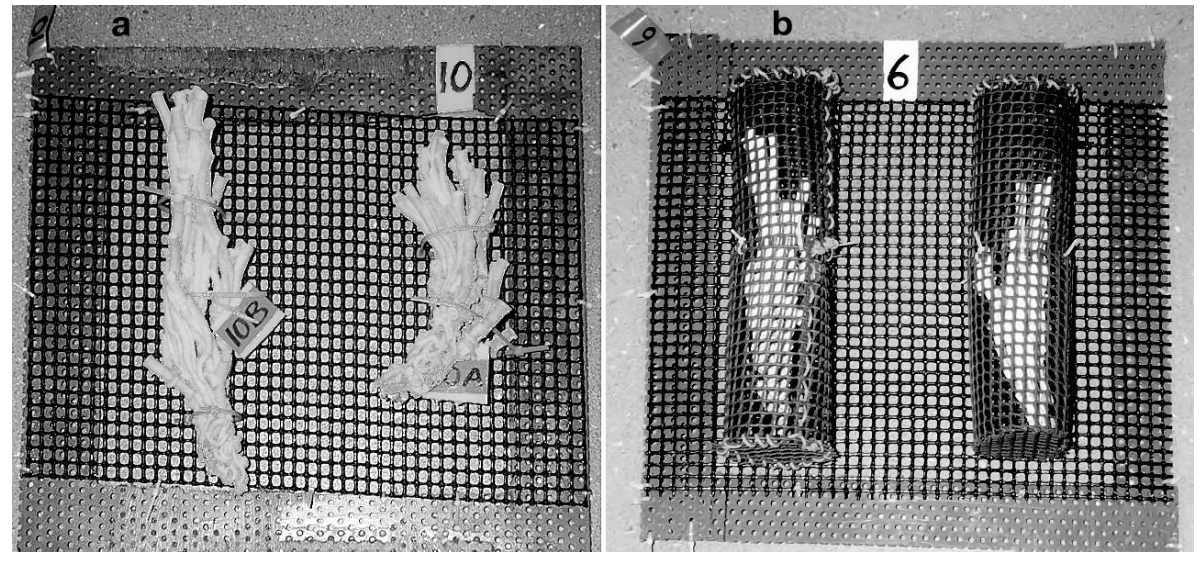

ery dives were made on 29 October 2005 ( 1 yr deployment), 24 August 2006 ( 2 yr), 2 September 2007 ( 3 yr) and 12 September 2009 ( 5 yr). On each occasion, 2 Open and 2 Caged panels were removed by a diver and returned to the surface, taking care to avoid any damage or loss of material from the panels. Additional dives were made between the recovery dates to check the condition of the remaining panels and reerect any fallen marker flags, but the skeletal fragments were not touched or interfered with in any way.

In the laboratory, the recovered panels were immersed overnight in fresh water, and the skeletal fragments were then carefully cleaned of soft-bodied fouling organisms using forceps. The mesh cylinders were cut open to allow access to the Caged fragments. Mobile invertebrates found inside the cylinders were identified and counted. Calcareous tubes, shells and colonies (serpulids, barnacles, bryozoans) recruited to the skeletal fragments and contributing to the carbonate balance were left in place. Living serpulids removed from the recovered skeletons were counted.

After removal of fouling biomass, the skeletal fragments were cleaned in running fresh water, with gentle 'hosing' into the tube apertures to wash out accumulated sediment. Any calcareous fragments breaking loose were retained for inclusion in the final weighing. The cleaned skeletons were then soaked in dilute sodium hypochlorite solution for $24 \mathrm{~h}$, washed again in fresh water, dried and re-weighed. Dry weight change was expressed as percentage increase or decrease relative to the original weight of each fragment. Tubes containing living Serpula vermicularis, representing animals recruited since panel deployment, were present on almost all recovered fragments. Distal portions of tubes recruited to Caged fragments often extended through the cylinder mesh. Projecting tube sections were included in the dry weight measurement if they clearly originated on the enclosed skeletal fragment, but tubes recruited onto the cylinder mesh were excluded.

\section{RESULTS}

\section{Weight change of serpulid skeletal fragments}

All panels and skeletal fragments deployed in 2004 were recovered successfully. Mean dry weight of Caged fragments was greater than original values after all deployment periods, with 15 out of 16 fragments showing a percentage increase (Fig. 3). The largest recorded increase was a near-doubling in weight $(\sim 97 \%)$ after $3 \mathrm{yr}$ in situ, but there was a wide range of variation at each time point. Mean weights for Open fragments showed relatively small percentage decreases at 1, 3 and $5 \mathrm{yr}$, with a small increase in mean weight at 2 yr (Fig. 3). The largest individual weight loss recorded was $\sim 49 \%$ for a fragment after 5 yr in situ.

After confirmation of data normality, percentage weight change was analysed in a 3-factor nested

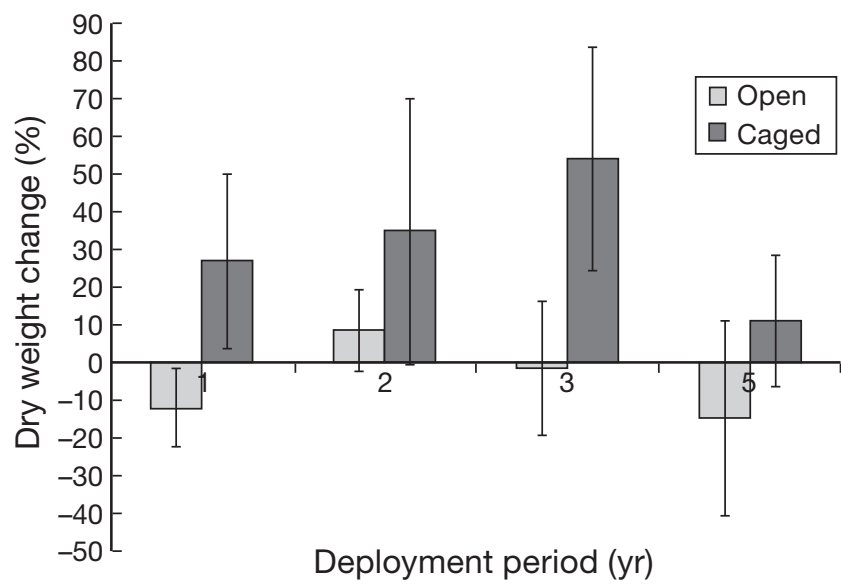

Fig. 3. Percentage change in dry weight of Open and Caged skeletal fragments after 1,2,3 or 5 yr deployment on the seabed in Loch Creran. Each bar represents the mean $( \pm \mathrm{SD})$ value of 4 fragments in each category 
Table 1. Summary for 3-factor nested analysis of variance for percentage weight change of serpulid skeletal fragments deployed in Loch Creran. Main effects are Treatment $(\mathrm{n}=2$; Open, Caged), Time ( $\mathrm{n}=4 ; 1,2,3$ and $5 \mathrm{yr})$ and Panel $(\mathrm{n}=8$, nested within Treatment and Time). Adj.: adjusted

\begin{tabular}{|lrrrrc|}
\hline Source & df & Adj. SS & Adj. MS & \multicolumn{1}{c|}{$F$} & $\mathrm{p}$ \\
\hline Treatment & 1 & 10772.9 & 10772.9 & 14.73 & 0.005 \\
Time & 3 & 4041.6 & 1347.2 & 1.84 & 0.218 \\
Treatment $\times$ Time & 3 & 1178.2 & 392.7 & 0.54 & 0.670 \\
Panel & 8 & 5851.6 & 731.5 & 1.74 & 0.165 \\
Error & 16 & 6726.6 & 420.4 & & \\
Total & 31 & 28571.0 & & & \\
\hline
\end{tabular}

analysis of variance (Zar 1984) with main effects Treatment ( $\mathrm{n}=2$, fixed factor), Time ( $\mathrm{n}=4$, fixed factor) and Panel ( $\mathrm{n}=8$, random factor nested within Treatment and Time). Only the Treatment main effect was statistically significant $(p=0.005)$, with Time, Treatment $x$ Time and Panel all non-significant (Table 1). These results confirm that percentage weight change showed no consistent trend over time, as illustrated by the plot of mean values in Fig. 3. The lack of a significant Panel effect reflects the wide differences sometimes recorded between adjacent fragments, especially in the Open treatment (for example, at $1 \mathrm{yr}$, weight change on Panel 15 was $+1.17 \%$ for Fragment A, versus $-24.23 \%$ for Fragment B).

\section{Role of serpulid recruitment in skeletal carbonate balance}

At the time of recovery, Open skeletal fragments and mesh cylinders were often fouled by foliose and filamentous red algae (Fig. 4). Open fragments were usually heavily silted and had few attached sessile invertebrates. In contrast, the mesh cylinders enclos- ing the Caged fragments always contained a variety of sessile and mobile invertebrates, of which the most common (often several individuals per cylinder) were the crab Pisidia longicornis, the brittlestar Ophiothrix fragilis and the terebellid polychaete Eupolymnia nebulosa. Other taxa included ascidians (Pyura microcosmus and Ascidia spp.), squat lobsters Galathea squamifera and several species of errant polychaetes and small scallops (Chlamys spp.). Five mesh cylinders contained 1 or 2 small specimens (test diameter 10 to $15 \mathrm{~mm}$ ) of the urchin Psammechinus miliaris. These urchins, and other invertebrates of adult size, must have entered as larvae or juveniles, taken up residence and eventually grown too large to exit through the mesh apertures.

Tubes containing living Serpula vermicularis were present on 14/16 Open and 15/16 Caged fragments (Fig. 5). Numbers were higher on Caged (maximum recorded $=40$, mean $\pm \mathrm{SD}=11.1 \pm 11.8$ tubes fragment $^{-1}$ ) than on Open fragments (maximum $=11$, mean $=3.6 \pm 3.5$ ). The number of living $S$. vermicularis was significantly positively correlated with percentage weight change in both treatments (Caged, Pearson correlation $=0.646, \mathrm{p}=0.007$; Open, Pearson correlation $=0.735, \mathrm{p}=0.001)$. Open fragments with 3 or more living $S$. vermicularis remained at steady-state or showed a relatively small $(<24 \%)$ weight increase, while weight loss was recorded from fragments carrying 2 or fewer occupied tubes (Fig. 6a). In the Caged treatment (Fig. 6b), the wide scatter of data points partly reflects the fact that the counts of living serpulids include tube size as an additional source of variation (recent recruits in small tubes and older recruits in larger tubes contribute equally). Empty tubes of serpulids that had settled on the fragments but died before panel recovery are also not represented in the analysis. These could not be reliably distinguished from the older tubes owing to the structural complexity of the skeletal fragments.
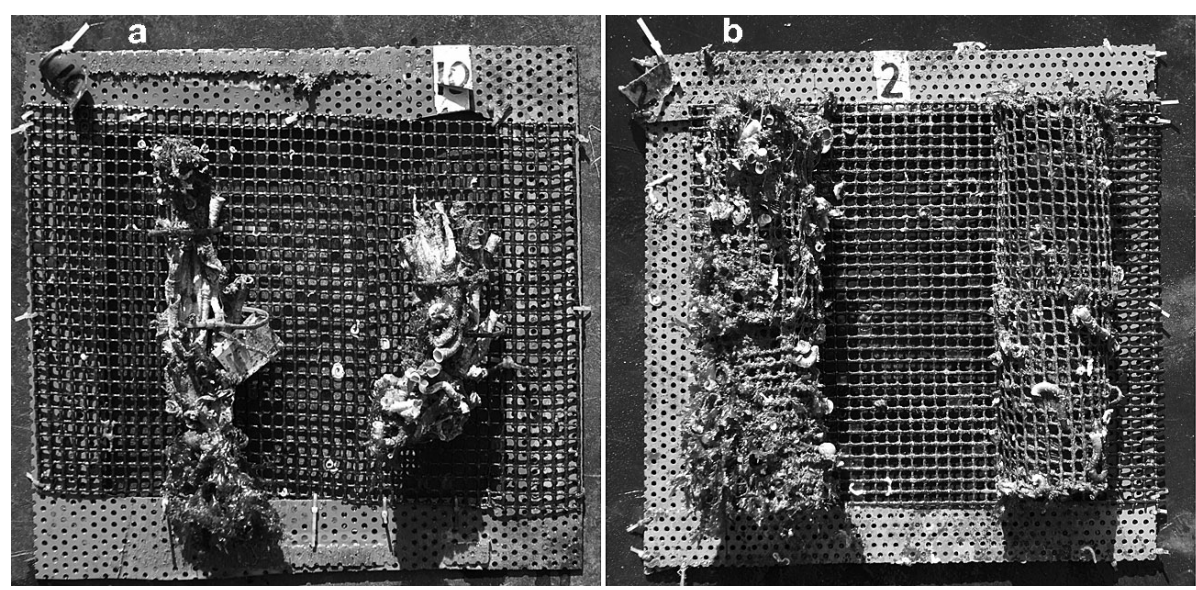

Fig. 4. Panels photographed on 12 September 2009 approximately $1 \mathrm{~h}$ after recovery from Loch Creran, following 5 yr in situ. (a) The Open panel is the same one shown pre-deployment in Fig. 2a. The skeletal fragments on the Open panel are colonized by foliose red algae. (b) The lefthand mesh cylinder of the Caged panel is also partly obscured by red algae. Tubes of Serpula vermicularis recruited during the deployment period can be seen projecting through the mesh of both cylinders 


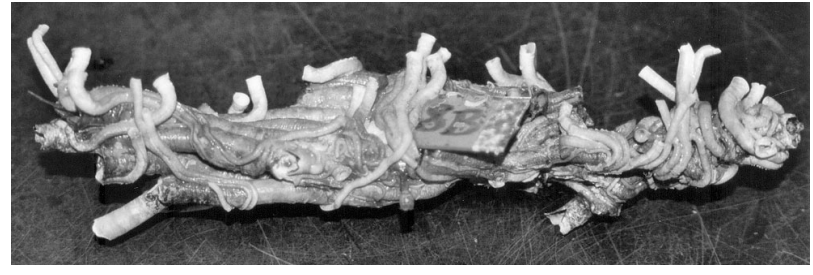

Fig. 5. Caged skeletal fragment (Fragment 8B), recovered on 29 October 2005 after just over $1 \mathrm{yr}$ in situ. The cleaned fragment carries $>20$ Serpula vermicularis tubes recruited during the deployment period, 19 of which were occupied by living worms at the time of recovery. The new tubes are mostly whiter than the underlying relict skeleton and follow an upwards growth trajectory away from the substratum. Dry weight of this fragment increased by $+18.59 \%$ over the $1 \mathrm{yr}$ deployment period. Length of fragment: $18 \mathrm{~cm}$

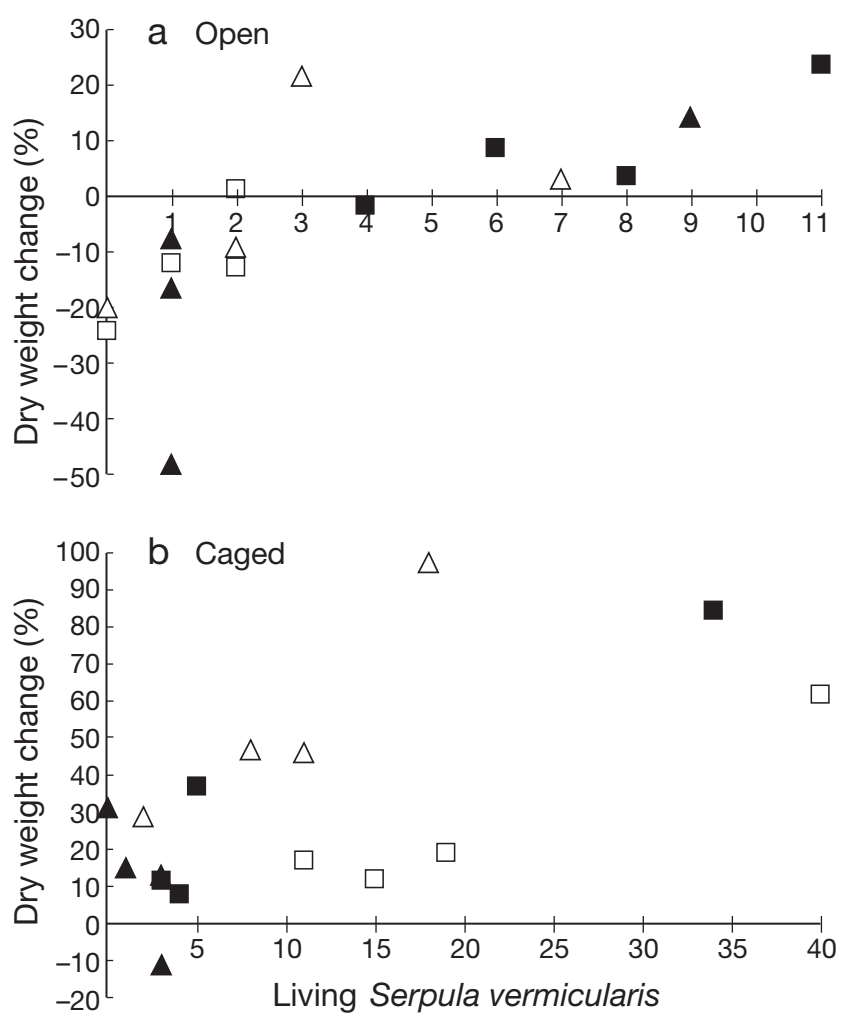

Fig. 6. Percentage dry weight change of (a) Open and (b) Caged skeletal fragments as a function of the number of living serpulid worms present on the fragments at the time of recovery. Symbols indicate the in situ deployment time of each fragment: 1 yr ( $\square), 2$ yr $(\square), 3$ yr $(\Delta), 5$ yr $(\mathbf{\Delta})$

\section{DISCUSSION}

\section{Taphonomic factors influencing tube residence time}

The main objective of this study was to investigate factors that might explain the lack of accumulated tube debris on the Loch Creran seafloor. The absence, over 5 yr, of a consistent trend towards weight loss on Open panels might suggest that relict tubes are highly persistent, but we must be cautious about extrapolating this result beyond the timescale of the experiment. Carbonate skeletons on the seafloor can show nonlinear patterns of weight change, with initial stability or increase resulting from epifaunal settlement, followed by weight loss and fragmentation brought on by the cumulative effects of bioerosion (Smith \& Nelson 2003). The experiment illustrates the challenge of quantifying processes operating over timescales much longer than the 2 to $3 \mathrm{yr}$ extent of a typical research project. At 5 yr duration, this is the longest bioerosion study yet reported from a high-latitude shelf sea (previous studies tabulated by Wisshak 2006), but is still insufficient to provide a definitive answer to the original question.

At the outset, the urchin Psammechinus miliaris was identified as a potential macroinvertebrate bioeroder of serpulid tube debris in Loch Creran. The caging treatment was designed to exclude this species, but the relatively small weight loss of Open fragments over 5 yr suggests that urchins did not significantly erode the dead serpulid tubes. The growth of foliose algae on the panels and cages (Fig. 4) may also be an indication of relatively low grazing pressure. On Open panels, the presence of 2 to 3 living serpulids per fragment marked an apparent threshold in mass balance, such that over a 5 yr timescale, tube growth of new recruits could outweigh the combined effects of bioerosion and chemical dissolution. The higher densities of living serpulids on Caged fragments may be explained by preferential settlement on the enclosed fragments, and/or a macroinvertebrate grazing effect exerted by the removal of new recruits rather than by erosion of the underlying dead skeleton.

Bioerosion by urchins and other large grazers may be more important in the tropics than at high latitudes (Wisshak 2006). In the Firth of Lorne, just outside Loch Creran, Akpan \& Farrow (1985) found that endolithic algae were major bioeroders of mollusc shells, but urchin grazing traces were recorded on only $9 \%$ of shells sampled. Urchin grazing was also of minor importance in the 2 yr Kosterfjord (Sweden) experiment, the most detailed study of high-latitude bioerosion undertaken to date (Wisshak et al. 2005). In laboratory experiments, Psammechinus miliaris fed on oyster shells heavily infested with boring sponges and polychaetes but did not attack unbored shells (Hancock 1957). The state of endolithic community development in serpulid tube debris may therefore determine the timing and extent of later bioerosion by urchins. Future studies should quantify the extent of endolithic bioerosion, identify the organisms responsible and estimate the frequency of urchin grazing traces on open and caged fragments using scanning electron 
microscopy, a method employed successfully in other carbonate bioerosion studies (Beuck \& Freiwald 2005, Wisshak 2006)

Chemical dissolution of carbonates in temperate shelf settings was formerly considered negligible owing to calcite and aragonite supersaturation of the overlying seawater (Smith \& Nelson 2003). However, it is now known that microbial respiration in organic-rich sediments can acidify porewaters to levels sufficient to erode at least the less stable carbonate phases (aragonite, high-Mg calcite). The process takes place at or near the sediment-water interface and is most rapid in oxic sediments irrigated by bioturbation (Aller 1982). The high calcite content of Serpula vermicularis tubes (93.6\%, Mg content not recorded, Vinn et al. 2008) should confer a relatively high durability but may be counteracted by the very high surface-to-volume ratio, which is probably more important than carbonate mineralogy in determining dissolution potential (Smith \& Nelson 2003). Observations from Linne Mhuirich, a small, sheltered inlet of Loch Sween in mid-Argyll (Fig. 1), provide an insight into longer-term tube persistence. Serpula vermicularis 'reefs' were recorded here from 1975 (R. Mitchell pers. comm. cited by Moore et al. 1998) to 1984 (Lumb 1986). A September 1994 survey (O. Paisley \& D. J. Hughes unpubl.) found that the 'reefs' had died out completely, leaving only dead skeletons, and no recovery has taken place since (Hughes et al. 2008 and subsequent pers. obs.). Relict tube material is still locally abundant and conspicuous at the sediment surface in Linne Mhuirich (Fig. 7a). Large fragments collected in July 2009 (Fig. 7b) must have persisted for at least $15 \mathrm{yr}$, and since the last record of living 'reefs' was in 1984, this material could be $>20$ yr old. Serpulid debris in Linne Mhuirich has therefore persisted for much longer than the $5 \mathrm{yr}$ duration of the Loch Creran experiment, despite the presence of abundant Psammechinus miliaris in both localities (author's pers. obs.).

Fjordic sea lochs receive large inputs of terrigenous organic matter (Ansell 1974, Loh et al. 2002) and are sites of rapid sediment accumulation (Cage \& Austin 2010). Deposition rate in the 'reef' zone around the periphery of Loch Creran has not been measured, but 5 yr in situ was insufficient to bury the panels. Experimental burial of skeletal fragments below the sediment-water interface would therefore be necessary to measure chemical dissolution rate in the absence of other factors leading to carbonate loss or accretion.

\section{Dynamics of Serpula vermicularis 'reefs' in Scottish sea lochs}

The taphonomic processes discussed above, which determine the residence time of tube debris, operate independently of the biological factors affecting population dynamics of Serpula vermicularis in Loch Creran. With respect to the lack of accumulated tube debris, the focus of attention to this point has been on processes leading to post mortem degradation of carbonate skeletons. However, an alternative hypothesis is that $S$. vermicularis 'reefs' have not existed in Loch Creran for long enough to generate thick deposits of skeletal debris. Anderson Smith (1887) described tubeworm aggregations in the loch in 1882, but the next published record comes from a diving survey in June 1989 (Connor 1990), and there is no published evidence confirming the presence of serpulid 'reefs' in Loch Creran between those dates. In November 1967,
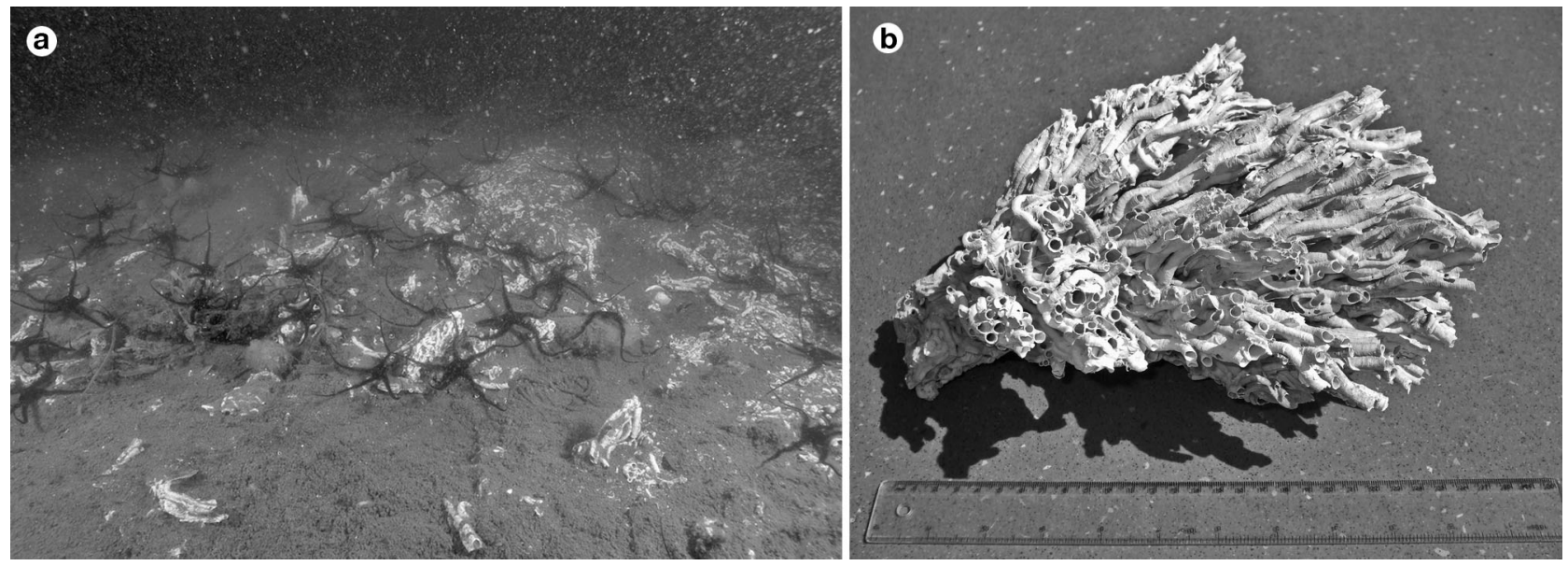

Fig. 7. (a) Seabed photograph taken in Linne Mhuirich, Loch Sween, on 17 May 2005, showing abundant relict Serpula vermicularis tube debris at the sediment surface. Black brittlestars are Ophiocomina nigra. Site location $55^{\circ} 59.90^{\prime} \mathrm{N}, 05^{\circ} 38.92^{\prime} \mathrm{W}$; water depth $\sim 4 \mathrm{~m}$. (b) Cleaned and dried mass of relict $S$. vermicularis tubes collected in Linne Mhuirich, Loch Sween, on 11 July 2009. Plastic ruler $(30 \mathrm{~cm})$ indicates scale. Collection site location $56^{\circ} 00.16^{\prime} \mathrm{N}, 05^{\circ} 38.47^{\prime} \mathrm{W}$; water depth $\sim 2 \mathrm{~m}$ 
Gage (1972) towed an Agassiz trawl through South Shian Bay, an area which now supports some of the best-developed serpulid 'reefs' in Loch Creran (Moore et al. 1998, 2009). $S$. vermicularis was recorded in the sample species list, but Gage did not mention it in the text. Since the tow formed part of a survey of the loch's benthic macrofauna, large masses of aggregated tubes would almost certainly have been noted if present in the trawl. In May 1969, benthic zonation was surveyed by scuba divers along a transect out from the loch's northern shore (to $15 \mathrm{~m}$ depth). The survey results (Gage 1974) again do not mention S. vermicularis, although the station falls within the current zone of 'reef' occurrence (Moore et al. 1998, 2009). Negative evidence of this kind must be treated with caution, but it raises the possibility that serpulid 'reefs' in Loch Creran have developed to their current state only since the late 1960s. In July 2006, small S. vermicularis aggregations were found at several stations in the upper basin of Loch Teacuis, a sea loch in Morvern, western Scotland (Fig. 1). None were recorded on a 1996 survey of the loch, suggesting that 'reef' formation here has begun very recently (Dodd et al. 2009). Alongside the apparent mass mortality in Linne Mhuirich, the Loch Teacuis discovery provides evidence that $S$. vermicularis 'reefs' in Scottish sea lochs may be relatively transient features, forming and disappearing over decadal timescales. If this hypothesis is correct, there may be no direct continuity between the existing 'reefs' in Loch Creran and those observed by Anderson Smith (1887) over a century ago. Coring of nearshore sediments, followed by sclerochronology or radiometric dating of any buried tube fragments could be investigated as a technique to clarify the long-term history of $S$. vermicularis 'reefs' in Scottish sea lochs.

Acknowledgements. I thank S. Thurston and H. Brown (SAMS) for their assistance in the field. This work was initiated during the 'Special Protection and Local Action for Species and Habitats' (SPLASH) programme funded by the Esmée Fairbairn Foundation, with additional financial support from Scottish Natural Heritage. Three reviewers provided constructive comments on the original manuscript. Finally, I congratulate Prof. R. Hughes of Bangor University on the occasion of his retirement and thank him for all his help in launching my own career in marine biology.

\section{LITERATURE CITED}

Akpan BE, Farrow GE (1985) Shell bioerosion in high-latitude low-energy environments: Firths of Clyde and Lorne, Scotland. Mar Geol 67:139-150

Aller RC (1982) Carbonate dissolution in nearshore terrigenous muds: the role of physical and biological reworking. J Geol 90:79-95

Anderson Smith W (1887) Loch Creran: notes from the West Highlands. Alexander Gardner, Paisley
Ansell AD (1974) Sedimentation of organic detritus in Lochs Etive and Creran, Argyll, Scotland. Mar Biol 27:263-273

Beuck L, Freiwald A (2005) Bioerosion patterns in a deepwater Lophelia pertusa (Scleractinia) thicket (Propeller Mound, northern Porcupine Seabight). In Freiwald A, Roberts JM (eds) Cold-water corals and ecosystems. Springer-Verlag, Berlin, p 915-936

Bosence DWJ (1979) The factors leading to aggregation and reef formation in Serpula vermicularis L. In: Larwood G, Rosen BR (eds) Biology and systematics of colonial organisms. Academic Press, London, NY, p 299-318

Cage AD, Austin WEN (2010) Marine climate variability during the last millennium: the Loch Sunart record, Scotland, UK. Quat Sci Rev 29:1633-1647

Chapman ND, Moore CG, Harries DB, Lyndon AR (2007) Recruitment patterns of Serpula vermicularis L. (Polychaeta, Serpulidae) in Loch Creran, Scotland. Estuar Coast Shelf Sci 73:598-606

Connor DW (1990) Survey of Lochs Linnhe, Eil, Creran and Aline. Nature Conservancy Council CSD Rep No. 1073. Nature Conservancy Council, Peterborough

> Dodd J, Baxter L, Hughes DJ (2009) Mapping Serpula vermicularis (Polychaeta: Serpulidae) aggregations in Loch Teacuis, western Scotland, a new record. Mar Biol Res 5: 200-205

Edwards A, Sharples F (1986) Scottish sea lochs: a catalogue. Scottish Marine Biological Association, Oban

Gage J (1972) A preliminary survey of the benthic macrofauna and sediments in Lochs Etive and Creran, sea-lochs along the west coast of Scotland. J Mar Biol Assoc UK 52: $237-276$

Gage J (1974) Shallow-water zonation of sea-loch benthos and its relation to hydrographic and other physical features. J Mar Biol Assoc UK 54:223-249

Hancock DA (1957) The feeding behaviour of the sea urchin Psammechinus miliaris (Gmelin) in the laboratory. Proc Zool Soc Lond 129:255-262

Heckel PH, Yablonsky D (1979) Reefs and other carbonate build-ups. In: Fairbridge RW, Jablonski D (eds) The encyclopedia of paleontology. Dowden, Hutchinson and Ross, Stroudsburg, PA, p 691-705

Hendrick VJ, Foster-Smith RL (2006) Sabellaria spinulosa reef: a scoring system for evaluating 'reefiness' in the context of the Habitats Directive. J Mar Biol Assoc UK 86: 665-677

Holt TJ, Rees EI, Hawkins SJ, Seed R (1998) Biogenic reefs, Vol IX. An overview of dynamic and sensitivity characteristics for conservation management of marine SACs. Scottish Association for Marine Science (UK Marine SACs Project). Available at www.ukmpas.org/pdf/Detailed_Marine_ Communities_Reports/biogreef.pdf

> Hughes DJ, Poloczanska ES, Dodd J (2008) Survivorship and tube growth of reef-building Serpula vermicularis (Polychaeta: Serpulidae) in two Scottish sea lochs. Aquat Conserv 18:117-129

Kelly MS (2000) The reproductive cycle of the sea urchin Psammechinus miliaris (Echinodermata: Echinoidea) in a Scottish sea loch. J Mar Biol Assoc UK 80:909-919

> Loh PS, Reeves AD, Overnell J, Harvey SM, Miller AEJ (2002) Assessment of terrigenous organic carbon input to the total organic carbon in sediments from Scottish transitional waters (sea lochs): methodology and preliminary results. Hydrol Earth Syst Sci 6:959-970

Lumb CM (1986) Loch Sween sublittoral survey, August 27 to September 8, 1984. Nature Conservancy Council CSD Rep No 722. Nature Conservancy Council, Peterborough

Minchin D (1987) Serpula vermicularis L. (Polychaeta: Ser- 
pulidae) reef communities from the west coast of Ireland. Ir Nat J 22:314-316

Moore CG, Saunders R, Harries DB (1998) The status and ecology of reefs of Serpula vermicularis L. (Polychaeta: Serpulidae) in Scotland. Aquat Conserv 8:645-656

Moore CG, Harries DB, Lyndon AR, Saunders GR, Conway TR (2003) Quantification of serpulid biogenic reef coverage of the sea bed (Polychaeta: Serpulidae) using a video transect technique. Aquat Conserv 13:137-146

Moore CG, Bates CR, Mair JM, Saunders GR, Harries DB, Lyndon AR (2009) Mapping serpulid worm reefs (Polychaeta: Serpulidae) for conservation management. Aquat Conserv 19:226-236

Poloczanska ES, Hughes DJ, Burrows MT (2004) Underwater television observations of Serpula vermicularis (L.) reefs and associated mobile fauna in Loch Creran, Scotland. Estuar Coast Shelf Sci 61:425-435

Rabaut M, Vincx M, Degraer S (2009) Do Lanice conchilega (sandmason) aggregations classify as reefs? Quantifying habitat modifying effects. Helgol Mar Res 63:37-46

Riding R (2002) Structure and composition of organic reefs and carbonate mud mounds: concepts and categories. Earth Sci Rev 58:163-231

Smith AM, Nelson CS (2003) Effects of early sea-floor pro-

Submitted: April 27, 2010; Accepted: November 30, 2010 cesses on the taphonomy of temperate shelf skeletal carbonate deposits. Earth Sci Rev 63:1-31

ten Hove HA (1979) Different causes of mass occurrence in serpulids. In: Larwood G, Rosen BR (eds) Biology and systematics of colonial organisms. Academic Press, London, p 281-298

ten Hove HA, van den Hurk P (1993) A review of recent and fossil serpulid 'reefs'; actuopalaeontology and the 'Upper Malm' serpulid limestones in NW Germany. Geol Mijnb 72:23-67

> Vinn O, ten Hove HA, Mutvei H, Kirsimäe K (2008) Ultrastructure and mineral composition of serpulid tubes (Polychaeta, Annelida). Zool J Linn Soc 154:633-650

Wisshak M (2006) High-latitude bioerosion: the Kosterfjord experiment. Lecture notes in Earth Sciences 109. Springer-Verlag, Heidelberg

Wisshak M, Tapanila L (eds) (2008) Current developments in bioerosion. Springer-Verlag, Berlin

Wisshak M, Gektidis M, Freiwald A, Lundälv T (2005) Bioerosion along a bathymetric gradient in a cold-temperate setting (Kosterfjord, SW Sweden): an experimental study. Facies 51:93-117

Zar JH (1984) Biostatistical analysis, 2nd edn. Prentice Hall International, Englewood Cliffs, NJ

Proofs received from author(s): March 3, 2011 